\title{
И.Н. Коробейников
}

\section{ХРОНОЛОГИЯ И КУЛЬТУРНАЯ ПРИНАДЛЕЖНОСТЬ ПАМЯТНИКОВ ЭПОХИ РАННЕГО МЕТАЛЛА НИЖНЕГО ПРИОБЬЯ}

\author{
Статья написана в рамках научного проекта № 8.1.19. 2016, \\ выполненного при поддержке Программы повышения международной конкурентоспособности ТГУ.
}

\begin{abstract}
В бронзовом веке наблюдается неравномерность социально-экономического развития разных районов Западной Сибири. Выделение археологической культуры вары-хадыта, основанное на результатах работ последних лет, способствует пониманию преемственности традиций местного населения в эпоху раннего бронзового века, а также уровню контактов со смежными культурами. Культурогенез Севера Западной Сибири заметно отличается от сопредельных территорий. Причиной тому могли быть периферийное положение и более низкая степень заселенности Ямала.

Ключевые слова: Нижнее Приобье; культура вары-хадыта; памятники раннего бронзового века.
\end{abstract}

Север Западной Сибири в археологическом отношении продолжает оставаться одним из наименее исследованных регионов России. Но, невзирая на суровые природные условия, это регион с богатой историей и своеобразными археологическими культурами. Несмотря на то что пока мы не можем отметить здесь наличие значительного количества памятников, имеющихся материалов вполне достаточно для того, чтобы выявить общие тенденции культурогенеза на этой территории в интересующий нас период.

В эпоху бронзового века особенно заметной становится неравномерность социально-экономического развития разных районов Западной Сибири. На юге этот период характеризуется становлением и развитием местной металлообработки меди и бронз, основанной на привозном сырье; на севере бронзовые изделия не носят массового характера. В присваивающем хозяйстве все большее значение приобретает рыболовство; характер охоты и собирательства также влиял на географию расселения местного населения. Становление металлообработки на сопредельных территориях неизбежно способствовало расширению и развитию культурных контактов.

Выделяя историографические вехи в процессе познания древней истории обозначенной местности, отметим, что здесь сложно четко отделить этапы накопления материала от его интерпретации и систематизации, поскольку эти процессы происходили параллельно. Сравнительно слабая археологическая изученность региона (по сравнению с таежными широтами или средним Зауральем) неизменно приводила к тому, что ряд исследователей (на отдельных этапах это связано с полным отсутствием прямых аналогий материальной культуры) проецировали историко-культурные реконструкции с более изученных территорий на Нижнее Приобье. Такой подход обусловлен ограниченным количеством имеющихся данных, но в то же время может быть отражением ландшафтных особенностей расселения.
Исследователи, характеризуя эпоху перехода от неолита к эпохе достаточно широкого распространения металлических предметов и способов металлообработки, употребляют самые разные понятия: «эпоха раннего металла», «ранний бронзовый век», «энеолит». Однако большинство памятников, отнесенных к этому периоду, металлических предметов, как и следов его обработки, не содержат, поэтому все заключения основаны на анализе массового керамического материала, орудий и различных способах датирования. В связи с появлением новых материалов и их различных интерпретаций, очевидно, назрела необходимость в выработке критериев с учетом региональных особенностей для вышеперечисленных определений. Сам термин «эпоха раннего металла» ввел М.Ф. Косарев для обозначения переходных памятников рубежа III-II тыс. до н.э. в лесостепном и южнотаежном Приобье [1. C. 19]. Позже он употребляется другими исследователями для хронологической атрибутации комплексов в различных ландшафтных зонах [2. С. 35-48; 3. С. 3-7; 4. C. 3-4].

Первым открытым памятником эпохи раннего металла в Нижнем Приобье стала «Салехардская стоянка», открытая М. Штекелисом в 1926 г. [5. С. 5] и обследованная Д.Н. Редриковым в конце 1920-х гг. Материалы эти были опубликованы, что привлекло внимание к древностям Нижнего Приобья. Первые стационарные исследования были проведены в 1946 г. В.Н. Чернецовым [6. С. 8] и В.И. Мошинской [7. C. 179-188, табл. III-IV]. Находки, происходящие из нижнего слоя стоянки, были отнесены к энеолиту раннему бронзовому веку.

Периодом энеолита и бронзы также датируются случайно открытые стоянка на р. Йоркута-яха в югозападной части Ямала [8. С. 80] и стоянка на р. Хэяха - притоке р. Щучья. На материалах стоянки Йоркуты-яха был выделен йоркутинский культурный тип, хронология которого до сих пор остается спорной. 
Первая попытка систематизации имеющихся данных была предпринята Л.П. Лашуком и Л.П. Хлобыстиным [9. С. 43-45]. Культурную принадлежность ряда памятников раннего металла исследователи, с одной стороны, выделяли в пернашорский вариант ортинской культуры, подчеркивая, таким образом, связи с территориями, лежащими к западу от Уральского хребта. С другой стороны, на севере Западной Сибири существовали поселения сартыньинской культуры, происходящие из таежных территорий [10. С. 40-62].

Основываясь на результатах работ последних лет, на территории Нижнего Приобья Е.А. Васильевым выделена культура раннего бронзового века, получившая название «вары-хадыта» (по одноименному памятнику) [11. С. 212]. Предполагается, что в первой половине середине II тыс. до н.э. культура занимала заполярные территории Нижнего Приобья и южной части п-ова Ямал. Генезис этой культуры связывается прежде всего с сартыньинской культурой, носители которой на одном из этапов ее развития мигрировали в более северные широты [Там же. С. 214]. Вероятно, именно пришельцы принесли сюда навыки металлообработки, сотовый геометризм в орнаментике и традицию изготовления ладьевидных сосудов.

К настоящему времени в ареал культуры варыхадыта включаются следующие памятники: стоянка Салехард I (нижний стратиграфический слой памятника) [7. С. 179-188], развеянное поселение Варыхадыта I [12. С. 24, 26], поселение Вары-хадыта II [Там же. С. 24-31] и открытое в 2009 г. поселение Горный Самотнёл I [13. С. 192-194; 14. C. 233-234].

Керамический комплекс культуры очень разнообразен и встречает многообразие как по форме изделий, так и по их декоративным особенностям. Наряду с посудой стандартных форм (сосуды с круглым устьем, с прямыми и слегка изогнутыми венчиками и вертикальными стенками, плавно переходящими в округлые или уплощенные днища) получили распространение ладьевидные емкости. Среди этих изделий выделяются уникальные блюда, украшенные зооморфными налепами (преимущественно в материалах поселения Варыхадыта II). Разнообразие форм сочетается с богатым декоративным разнообразием.

Техника нанесения узора, набор декоративных мотивов и организация орнаментального пространства определили выделение трех орнаментальных стилей геометрического, фигурно-штампового, отступающенакольчатого, которые обусловливают многокомпонентность культуры и отражают ее генетические связи.

«Стиль сотового геометризма», характеризующийся сложными геометрическими композициями (зигзаги, прямоугольники, ромбы, шестиугольники-соты), выполненный преимущественно гладким штампом, генетически связан с аналогичными мотивами в сартыньинской керамике.

Фигурно-штамповые узоры восходят к местной орнаментальной традиции [8; 9. С. 44]. Керамика, укра- шенная уголковыми, дуговидными и круглыми штампами в сочетании с оттисками гребенчатых и гладких орнаментиров, соотносится с материалами памятников йоркутинского типа, локализовавшихся в энеолитическое время в низовьях Оби и на Южном Ямале. Наличие орнамента шагающей гребенки в сочетании с этими штампами также указывает на йоркутинские истоки этой традиции.

Установить истоки отступающе-накольчатого стиля, наносимого палочкой или лопаточкой, в настоящий момент невозможно, так как посуда, декорированная в подобном стиле, была распространена в таежной полосе Западной Сибири едва ли не повсеместно.

Следовательно, происхождение культуры варыхадыта - это проблема интеграции трех компонентов сартыньинского, йоркутинского и компонента с отступающе-накольчатой керамикой, истоки которого еще предстоит определить.

Наравне с проблемой поиска истоков культуры вары-хадыта существует проблема внутреннего единства. Например, керамика, найденная на поселении Горный Самотнёл I, обнаруживает наибольшую близость (по основным морфологическим и декоративным показателям) с керамическим комплексом поселения Варыхадыта II, что позволяет включить этот памятник в культурный ареал. Вместе с тем она имеет некоторые специфические особенности в декорировании, в частности использование широкого плоского штампа с фигурной ячеистой нарезкой [14. С. 234], а также более древние радиоуглеродные даты, вследствие чего O.С. Кудрич относит поселение Горный Самотнёл I к эпохе энеолита.

Культура вары-хадыта - явление уникальное для археологии Западной Сибири, показывающее, насколько удивительным может быть уровень художественного развития и эстетического восприятия у носителей данной культуры, проживавших в столь неблагоприятных условиях. Поиск, открытие новых памятников и обработка найденного археологического материала помогут очертить ареалы распространения культуры варыхадыта, позволят судить о контактах её носителей.

Первостепенной задачей расширения наших знаний о культуре вары-хадыта видится систематическое проведение раскопок со вскрытием значительной площади. И в этом смысле археологические работы на памятнике Горный Самотнёл являются хорошим знаком. Итоги новых полевых сезонов позволят судить о результативности проведенной нами работы. Включение же обработанной коллекции Горного Самотнёла в научный оборот помогут уточнить сложившуюся модель культурогенеза.

Если взглянуть на географическую карту, можно отметить большие «белые пятна» в ареале данной культуры. Проанализировав географическое положение памятников, можно сделать следующий вывод. Их местонахождение в правобережье (стоянка Салехард I на берегу р. Полуй, правом притоке р. Оби, и поселение 
Горный Самотнёл I на высокой террасе одноименного мыса) и левобережье (поселения Вары-хадыта I, II на левом берегу р. Вары-Хадыта) р. Оби подтверждает вывод о логичности продвижения из более южных широт. Поэтому вопрос о проведении археологических разведок особенно актуален. Проведенная нами в 2012 г. разведка в Приуральском районе ЯмалоНенецкого автономного округа, в правобережье Оби, однако, показала отсутствие памятников данной эпохи [15], что побуждает нас сосредоточить внимание на возможностях геоморфологического подхода к решению обозначенной проблемы. Наиболее перспективным участком для поиска памятников культуры варыхадыта и вообще памятников эпохи раннего металла нам представляется бассейн р. Щучьей с многочисленными притоками и озерами. В 1949 г. Г.А. Чернов обнаружил здесь девять стоянок [16. С. 96]. Сборы керамики на некоторых из них находят аналогии среди материалов стоянки Салехард I.

Учитывая особенности каждого памятника, мы можем предположить, что культурогенез данного регио- на, при наличии своеобразного социальноэкономического уклада, заметно отличается от сопредельных территорий. Причиной тому могли быть периферийное положение и более низкая степень заселенности Ямала. Возможно, культурные ареалы не будут иметь здесь сплошной характер.

Для эпохи раннего металла Севера Западной Сибири характерна «мозаичность» культурного пространства. В то время здесь существовало несколько культур и культурных типов, что подтверждается многообразием технологических и декоративных особенностей оформления керамических сосудов. В настоящий момент мы не можем установить, связано ли это со степенью исследования региона либо отражает реальную ситуацию в древности. Пришедшие сюда в разное время отличные по происхождению коллективы и придавали культурно-исторической картине ту «мозаичность», которая постепенно, в процессе контактов между ними, привела к относительной культурной однородности населения в эпоху финальной бронзы.

\section{ЛИТЕРАТУРА}

1. Косарев М.Ф. Древние культуры Томско-Нарымского Приобья. М., 1974. 220 с.

2. Молодин В.И. Эпоха неолита и бронзы лесостепного Обь-Иртышья. Новосибирск, 1977. 174 с.

3. Кирюшин Ю.Ф. Поселение Тух-Эмтор - памятник Васюганского Приобья // Из истории Сибири. Томск, 1976. Вып. 19. С. 3-29.

4. Васильев Е.А. Энеолитическое время в бассейне р. Вах // Вопросы археологии и этнографии Сибири. Томск, 1978. С. 3-12.

5. Визгалов Г.П., Кардаш О.В. Атлас археологических памятников города Салехарда. Буклет. Салехард, 2005.23 с.

6. Чернецов В.Н. Древняя история Нижнего Приобья // Древняя история Нижнего Приобья. МИА СССР. М., 1953. Вып. 35. С. 7-71.

7. Мошинская В.И. Жилище усть-полуйской культуры и стоянка эпохи бронзы в Салехарде // Древняя история Нижнего Приобья. МИА СССР. М., 1953. Вып. 35. С. 179-188.

8. Королев Ю.Г., Хлобыстин Л.П. Йоркутинская стоянка на полуострове Ямал. М., 1969. С. $79-83$.

9. Лашук Л.П., Хлобыстин Л.П. Север Западной Сибири в эпоху бронзы // Краткие сообщения Института археологии Академии наук СССР. М., 1986. Вып. 185. С. 43-50.

10. Васильев Е.А. Хронология и культурная принадлежность памятников эпохи раннего металла в бассейне Северной Сосьвы // Этнокультурные процессы в Западной Сибири. Томск, 1983. С. 40-62.

11. Васильев Е.А. Культура вары-хадыта и проблемы культурогенеза Северо-Западной Сибири в раннем бронзовом веке // Труды III (ХІХ) Всероссийского археологического съезда. Великий Новгород, 2011. Т. І. С. 212-214.

12. Васильев Е.А. Поселение Вары-хадыта II и проблемы первобытной археологии Ямала // Материалы научно-исследовательской конференции по итогам полевых исследований 1999 года. Салехард, 2000. Вып. 3. С. 24-31.

13. Кудрич О.С. Керамика поселения Горный Самотнёл как компонент формирования культуры населения низовий Оби в эпоху энеолита бронзы // Материалы XV Международной Западно-Сибирской археолого-этнографической конференции. Томск, 2010. С. 192-194.

14. Кудрич О.С. Север Западной Сибири: новые источники по энеолиту - раннему бронзовому веку низовий Оби // Труды III (ХІХ) Всероссийского археологического съезда. Великий Новгород, 2011. Т. І. С. 233-234.

15. Коробейников И.Н. Отчет о научно-исследовательской работе «Археологическая разведка в Нижнем Приобье (Приуральский район ЯмалоНенецкого автономного округа) в 2012 году» // Архив Музея археологии и этнографии Сибири Томского государственного университета (без номера).

16. Чернов Г.А. Археологические находки на р. Щучьей // Краткие сообщения Института истории материальной культуры. М. : Изд-во АН CCCP, 1951. Вып. XL. С. 96-104.

Korobeynikov Ilya N. Tomsk State University (Tomsk, Russia). E-mail: russianViking@yandex.ru

CHRONOLOGY AND CULTURAL ASSOCIATION OF ARCHAEOLOGICAL SITES IN EARLY METAL AGE OF THE LOWER OB.

Keywords: Lower Ob; archaeological culture vary-khadyta; archaeological sites of early Bronze Age.

North Western Siberia remains one of the least explored regions of Russian Federation. But we believe that the material at our disposal is enough to identify common trends in cultural genesis in this area. In the Bronze Age becomes particularly noticeable uneven socioeconomic development of different regions of Western Siberia. On south this period is characterized by the formation and development of local metalworking of cuprum and bronze, which based on imported raw materials; on north bronze things are not widespread. In appropriating economy fishery is becoming more important role; the nature of hunting and gathering, also influenced the geography of resettlement of the local population. The formation of metalworking on contiguous territories will inevitably contribute to the expansion and development of cultural contacts. Low archaeological study of the region led to the fact that a number of researchers projected the reconstruction of historical and cultural areas with a more studied zones on the Lower Ob. Advent of new materials and their various interpretations, obviously, there is a need to develop new criterions for the concepts of "Chalcolithic", "Early Metal Age" and "Early Bronze Age" from a regional perspective to the above definitions. Archaeological culture of Early Bronze Age, called "vary-khadyta", that has been allocated by E.A. Vasiliev in the Lower Ob, at the first half - middle of the II millennium BC expand the Lower Ob region and the southern part of the Yamal Peninsula. The genesis of this culture is associated primarily with sartyninsk culture, which are likely 
to migrate to more northern latitudes and brought here metalworking skills, geometrism cell in the ornamentation and manufacturing tradition of boat-shaped vessels. The genesis of vary-khadyta culture is the problem of integration of the three components - sartyninsk, yorkutinsk and component with retreat-prick ceramics, whose genesis of is not determined now. Vary-khadyta culture is a unique phenomenon in the archeology of Western Siberia. This ancient people demonstrated incredible level of artistic development and aesthetic perception, that incarnated in the various areas of material culture. Search and discovery of new archaeological sites and the processing of the found archaeological material help us to identify areas of cultural expansion of this archaeological culture.

\section{REFERENCES}

1. Kosarev, M.F. (1974) Drevnie kul'tury Tomsko-Narymskogo Priob'ya [Ancient cultures of the Tomsk-Narym Ob]. Moscow.

2. Molodin, V.I. (1977) Epokha neolita i bronzy lesostepnogo Ob'-Irtysh'ya [The Neolithic and Bronze epochs of the steppe Ob-Irtysh]. Novosibirsk: Nauka.

3. Kiryushin, Yu.F. (1976) Poselenie Tukh-Emtor - pamyatnik Vasyuganskogo Priob'ya [Settlement Tukh-Emtor - a monument of Vasyugan Ob Area]. In: Lukina, N.V. \& Tomilov, N.A. (eds) Iz istorii Sibiri [From the history of Siberia]. Tomsk: Tomsk State University. pp. 3-29.

4. Vasiliev, E.A. (1978) Eneoliticheskoe vremya v basseyne r. Vakh [The Chalcolithic period in the basin of the Vakh]. In: Dremov, V.A. (ed.) Voprosy arkheologii i etnografii Sibiri [Problems of Archeology and Ethnography of Siberia]. Tomsk: Tomsk State University. pp. 3-12.

5. Vizgalov, G.P. \& Kardash, O.V. (2005) Atlas arkheologicheskikh pamyatnikov goroda Salekharda [The atlas of Salekhard archaeological monuments]. Salekhard.

6. Chernetsov, V.N. (1953) Drevnyaya istoriya Nizhnego Priob'ya [The ancient history of the Lower Ob]. Materialy i issledovaniya po arkheologii. 35. pp. 7-71.

7. Moshinskaya, V.I. (1953) Zhilishche ust'-poluyskoy kul'tury i stoyanka epokhi bronzy v Salekharde [The residence of Ust-Poluyskaya culture and the man site of the Bronze Age in Salekhard]. Materialy i issledovaniya po arkheologii. 35. pp. 179-188.

8. Korolev, Yu.G. \& Khlobystin, L.P. (1969) Yorkutinskaya stoyanka na poluostrove Yamal [Yorkutinskaya man site on the Yamal Peninsula]. Moscow: [s.n.]. pp. 79-83.

9. Lashuk, L.P. \& Khlobystin, L.P. (1986) Sever Zapadnoy Sibiri v epokhu bronzy [The north of Western Siberia in the Bronze Age]. In: Kruglikova, I.T. (ed.) Kratkie soobshcheniya Instituta arkheologii Akademii nauk SSSR [The brief reports of the Institute of Archaeology of the USSR Academy of Sciences]. Issue 185. Moscow: Nauka. pp. 43-50.

10. Vasiliev, E.A. (1983) Khronologiya i kul'turnaya prinadlezhnost' pamyatnikov epokhi rannego metalla v basseyne Severnoy Sos'vy [The chronology and cultural belonging of the monuments of the early metal era in the North Sosva basin]. In: Glushkov, I.G., Petrov, A.I., Matyushchenko, B.I. et al. Etnokul'turnye protsessy v Zapadnoy Sibiri [Ethno-cultural processes in Western Siberia]. Tomsk: Tomsk State University. pp. 40-62.

11. Vasiliev, E.A. (2011) Kul'tura Vary-Khadyta i problemy kul'turogeneza Severo-Zapadnoy Sibiri v rannem bronzovom veke [The culture of VaryHadyta and problems of cultural genesis of North-Western Siberia in the early Bronze Age]. In: Makarov, N.A. \& Nosov, E.N. (eds) Trudy III (XIX) Vserossiyskogo arkheologicheskogo s"ezda [Proceedings of the Third (19) All-Russian Archaeological Congress]. Vol. 1. Veliky Novgorod: RAS. pp. 212-214.

12. Vasiliev, E.A. (2000) Poselenie Vary-Khadyta II i problemy pervobytnoy arkheologii Yamala [Vary-Hadyt-II and the problems of prehistoric archeology in Yamal]. In: Materialy nauchno-issledovatel'skoy konferentsii po itogam polevykh issledovaniy 1999 goda [Proceedings of the scientificresearch conference on the results of field research in 1999]. Salekhard: Krasniy Sever, pp. 24-31.

13. Kudrich, O.S. (2010) [The pottery of Gornyy Samotnël in the formation of culture of the lower Ob in the Eneolithic - Bronze Age]. Materialy XV Mezhdunarodnoy Zapadno-Sibirskoy arkheologo-etnograficheskoy konferentsii [Proceedings of the 15th International West Siberian Archaeological and Ethnographic Conference]. Tomsk: Tomsk State University. pp. 192-194. (In Russian).

14. Kudrich, O.S. (2011) Sever Zapadnoy Sibiri: novye istochniki po eneolitu-rannemu bronzovomu veku nizoviy Obi [The north of Western Siberia: New sources for Eneolithic and early Bronze Age in the Lower Ob]. In: Makarov, N.A. \& Nosov, E.N. (eds) Trudy III (XIX) Vserossiyskogo arkheologicheskogo s"ezda [Proceedings of the Third (19) All-Russian Archaeological Congress]. Vol. 1. Veliky Novgorod: RAS. pp. $233-234$.

15. Korobeynikov, I.N. (n.d.) Otchet o nauchno-issledovatel'skoy rabote "Arkheologicheskaya razvedka v Nizhnem Priob'e (Priural'skiy rayon YamaloNenetskogo avtonomnogo okruga) v 2012 godu" [The report on research "Archaeological Reconnaissance of the Lower Ob (Priuralsky region of Yamalo-Nenets Autonomous District) in 2012”]. The Archive of the Museum of Archaeology and Ethnography of Siberia, Tomsk State University (no number)

16. Chernov, G.A. (1951) Arkheologicheskie nakhodki na r. Shchuch'ey [Archaeological finds on the river. Shchuchya]. In: Kratkie soobshcheniya Instituta istorii material'noy kul'tury [Brief reports of the Institute of History of Material Culture]. Issue XL. Moscow: USSR AS. pp. 96-104. 